\title{
„OD KACERZA DO WSPÓLNEGO NAUCZYCIELA” Marcin Luter w niemieckiej katolickiej historiografii kościelnej XX wieku*
}

Kiedy w r. 1925 pierwszy niemiecki jezuita i kontrreformator Piotr Kanizjusz został ogłoszony świętym, „L’Osservatore Romano” z 21 maja skorzystało z okazji, ażeby porównać wzajemnie Kanizjusza i niemieckiego reformatora Lutra. Wniosek brzmiał: „Obydwa imiona mają się do siebie jak światło do cienia, jak herezja i stryczek, który ją dusi". W tym samym roku i z tej samej okazji członek rzymskiej Kongregacji Obrzędów Carlo Salotti znalazł jeszcze bardziej ostre słowa, kiedy mówił o Lutrze jako o ,człowieku z piekła rodem”, który zniszczył ,całą kulturę", a Niemców uczynił „okrutnym, krwiożerczym, niszczycielskim narodem". Nawet jezuici nieusposobieni przecież przychylnie do protestantyzmu czuli się zobowiązani przytępić i sprostować słowa Salottiego.

Negatywna ocena Lutra przez oficjalne czynniki rzymskie nie została zrewidowana także w następnych dziesięcioleciach. Jeszcze 16 listopada 1956 r. „L’Osservatore Romano” określiło Lutra jako ,,herezjarchę” i podjęło przez to polemikę XVI wieku. Tym bardziej zadziwił fakt, kiedy około 14 lat później, mianowicie we wrześniu 1970 r. kard. Willebrands, sekretarz rzymskiego Sekretariatu Jedności [Chrześcijan], z okazji Kongresu Światowego Związku Luterańskiego w Evian koło Genewy powiedział, co następuje: „W ciągu wieków osoba Marcina Lutra nie zawsze była oceniana słusznie przez stronę katolicką; jego teologia nie zawsze była przekazywana właściwie. Nie służyło to ani prawdzie, ani miłości, ani tym samym jedności, którą usiłujemy urzeczywistnić między Wami i Kościołem katolickim. Należy jednak z drugiej strony podkreślić z radością, że w ostatnich dziesięcioleciach wśród uczonych katolickich wzrosło naukowo dokładniejsze rozumienie reformacji, a przez to także postaci Lutra i jego teologii. [...] Któż ośmieliłby się dzisiaj [...] zaprzeczyć, że Marcin Luter był osobistością głęboko religijną, że z uczciwością i oddaniem poszukiwał ewangelicznego orędzia? [...] Może on być dla nas wspólnym na uczycielem w tym, że Bóg musi zawsze pozostać

* Poniższy tekst jest przekładem referatu wygłoszonego w języku niemieckim przez Autora w Papieskiej Akademii Teologicznej w Krakowie 11 V 1985 r. 
Panem oraz że nasza najważniejsza odpowiedź ludzka musi zachować absolutne zawierzenie i uwielbienie Boga".

Wówczas można było jeszcze przypuszczać, że kard. Willebrands mówił w Evian o ,wspólnym nauczycielu" w euforii uwarunkowanej sytuacyjnie, z racji swego wystąpienia przed Swiatowym Związkiem Luterańskim. Jednakże dalszy rozwój wydarzeń wykluczył taką interpretację. Kiedy mianowicie w r. 1983 obchodzono na całym świecie 500. rocznicę urodzin Marcina Lutra, papież Jan Paweł II 31 października tr., z okazji tzw. Swięta Reformacji, napisał list do kard. Willebrandsa, w którym m.in. powiedział:

Lstotnie, naukowe badania uczonych tak ewangelickich, jak i katolickich, badania, w których osiągnięto już znaczną zbieżność poglądów, doprowadziły do nakreślenia pełniejszego i bardziej zróżnicowanego obrazu osobowości Lutra oraz skomplikowanego wątku rzeczywistości historycznej, społecznej, politycanej i kościelnej pierwszej połowy XVI wieku. Przekonywująco dostrzegalna stała się przy tym głęboka religijnośé Lutra, którego pociągała gorąca namiętność do pyitania o wieczne zbawienie. Stało się też oczywiście jasne, że zerwania jedności Kościoła nie możła sprowadzić ani do arogancji Pasterzy Kościoła katolickiego, ani też jedynie do braķu zrozumienia prawdziwego katolicyzmu ze strony Lutra, nawet jeśli te okoliczności mogły odegrać pewną rolę. Decyzje, o które chodziło, sięgały głębiej. W sporze o stosunek między wiarą a tradycją w grę wchodziły zasadnicze kwestie właściwego wyłożenia i przyswojenia wiary chrześcijańskiej, których działania powodującego podział w Kościele nie udało się przezwyciężyć li tylko samym historycznym rozumieniem. Dlatego w spojrzeniu na Marcina Lutra i w poszukiwaniu przywrócenia jedności jest konieczny podwójny wysiłek. Najpierw jest rzeczą ważną kontynuowanie sumiennej pracy historycznej. Chodzi o uzyskanie właściwego obrazu Reformatora, jak i całej epoki reformacji oraz osób w niej działających, poprzez badanie pozbawione uprzedzeń i kierowanie jedynie poszukiwaniem prawdy. Tam, gdzie jest wina, musi ona zostać uznana, obojętne jakiej strony dotyczy. Tam, gdzie polemika zaciemnika spojrzenie, musi ono zostać rozjaśnione, znowu niezależnie od tego, o którą stronę chodzi. Przy tym nie może nami kierować zamiar stania się sędziami historii, lecz cel powinien być jeden - poznać lepiej i przez to stać się bardziej podatnymi na przyjęcie prawdy. Tylko w takiej postawie, która poddaje się oczyszczeniu przez: prawdę bez zastrzeżeń, będziemy mogli znaleźć wspólne zrozumienie sprawy mịnionej i w ten sposób uzyskać nowe punkty wyjścia do rozmowy. I to jest druga sprawa, tutaj nieodzowna: historyczne wyjaśnienie problemu, zwracające się ku przeszłości i w swej ciągle odradzającej się ważności musi iść łącznie z dialogịm wiary, w którym tu i teraz szukamy jedności.

Można by mnożyć cytaty. Można by wskazać na gest odwiedzin przez papieża niemieckiej parafii ewangelicko-luterańskiej w Rzymie 11 grudnia 1983 r. Można by przytoczyć mowę, jaką wygłosił kard. Höffner w Wormacji wobec luterańskiego Synodu jesienią tego samego roku. Rezultat jest zawsze ten sam; oficjalny Kościół katolicki uzyskał $\mathrm{w}$ ostatnich dziesięcioleciach nowy obraz Lutra: z kacerza w "L'Osservatore” z r. 
1925 i z herezjarchy roku 1956 stał się Luter w r. 1970 ,wspólnym nauczycielem", a w r. 1983 wybitną w dziejach religii postacią, która „pałała gorącą żarliwością w pytaniu o wieczne zbawienie”.

Jeżeli dzisiaj ma się mówić o Marcinie Lutrze w niemieckiej katolickiej historiografii kościelnej $\mathrm{XX}$ wieku, to powyższe cytaty powinny służyć nie tylko jako wygodne wprowadzenie do zmian obrazu Lutra. Dzieje się tak dlatego, że zdumiewające zmiany oficjalnego stanowiska, ukoronowane listem papieskim z r. 1983, mają bardzo silny związek z katolicką historiografią. Otóż dla obrazu Lutra u katolickich historyków Kościoła w Niemczech dadzą się z tego wyprowadzić dwie tezy, które zostaną w dalszej części rozwinięte:

Te z a 1: List papieski odzwierciedla droge oraz istotne wyniki katolickiej niemieckiej historiografii kościelnej $i$ bez tych badań bytyby one nie do pomyślenia.

T e z a 2: Droga katolickiego obrazu Lutra ,od kacerza do wspólnego nauczyciela" jest $w$ liście oficjalnie potwierdzona, lecz także zrelatywizowana wyznaczeniem granic historycznego rozumienia $i$ podkreśleniem koniecznego uzupetnienia poprzez dogmatyczne badanie $i$ dyskusję.

Kiedy rozpatruje się niemiecką historiografię, można uczynić zadziwiające spostrzeżenie: od lat katolicki obraz Lutra jest centralnym tematem bardzo obfitego piśmiennictwa historycznego. Powodem tego mogły być zarówno przemiany tego obrazu i żmudne drogi jego poszukiwań, jak tė̇ pogłębione w nich, po części nowe i budzące zaciekawienie spojrzenie na Lutra, co uczyniło je wdzięcznym przedmiotem obserwacji historyczno-kościelnego procesu poznawczego. Ukazywanie katolickiego obrazu Lutra wychodzi spod pióra naukowców wszystkich wyznań. Ich wachlarz rozciąga się od Gottfrieda Marona, przewodniczącego wpływowego związku ewangelickiego w Niemczech, poprzez społecznego pisarza Rainera Wohlfeila aż do katolickich teologów, jak Hubert Jedin i Peter Manns, aby wymienić tylko niektórych. Z całego bogactwa uzyskanych przez te prace wyników zostaną w dalszych naszych rozważaniach wydobyte i porównane $\mathrm{z}$ listem papieskim jedynie najważniejsze $\mathrm{z}$ nich.

Chociaż sformułowanie to jest trochę nieprecyzyjne, można powiedzieć, że po różnych fazach rozwoju i nawarstwieniach pozytywny i naukowo wytrzymały obraz Lutra w katolickiej historiografii kościelnej w Niemczech rozwinął się dopiero w XX wieku. Pierwsze wysiłki, jakie pódjął Döllinger około 1828 r. na gruncie ścisłej metody historycznej, zostały wkrótce unicestwione przez zaostrzający się klimat konfesyjny od cźasu 
zamieszek kolońskich w latach 1837-1838, gdzie chodziło o małżeństwa mieszane, od kulturkampfu z r. 1870 (dotknął on również katolicką Polskę) oraz przez wysoce wystylizowany obraz Lutra jako bohatera niemiecko-narcdowego w zabarwionej protestancko kaizerowskiej Rzeszy. Kiedy sławny historyk Friedrich von Betzold napisał w r. 1890 w swej Historii niemieckiej reformacji (s. 872), że „,bez Lutra nie mielibyśmy ani Kanta ani Goethego, a bez protestanckiego i antykaizerowskiego pochodzenia państwa pruskiego - naszej nowej Rzeszy Niemieckiej", słowa te nie były $\mathrm{z}$ pewnością właściwym bodźcem do wywołania przyjaznego echa ze strony katolickiej. Na przełomie wieków propagowano w Austrii „ruch uwolnienia od Rzymu" przy poparciu ewangelickiego Związku Kościoła Luterańskiego, a jednocześnie współczesny liberalny protestantyzm zakwestionawał treściowo wiarę. Skłoniło to dominikanina Heinricha Deniflego, z pochodzenia Tyrolczyka, poza tym uznanego na arenie międzynarodowej znawcy średniowiecznej historii teologii i nauki, do napisania książki, którą zamierzał zniszczyć protestancką „legendę o Lutrze” przy pomocy zarówno zdumiewającej uczoności, ale także grubiańskiej polemiki. Jej tytuł brzmiał: Luther und Luthertum in ihrer ersten Entwicklung; ukazała się ona po raz pierwszy w r. 1903 w Moguncji. Zaledwie w rok później okazało się konieczne drugie wydanie. Zamierzenie Deniflego było jednoznaczne: Luter ma być zdemaskowany jako kłamca, człowiek moralnie zdeprawowany i niepohamowany liberał, a reformacja miała za zadanie kontynuować i uprawomocnić jego moralny sprzeciw. Nie ma potrzeby wchodzenia w szczegóły polemicznej i przerażającej w tonie książki, zajmującej się szczególnie tematem: Luter a stan zakonny. Już wówczas nie wszyscy katoliccy historycy Kościoła byli gotowi zaakceptować ten styl. Sebastian Merkle z Würzburga, do którego musimy jeszcze powrócić, sprzeciwił się gwałtownie Deniflemu w obszernej recenzji i wprowadził przez to obiektywniejszą ocenę Lutra. W jednym jednak punkcie dostarczył Denifle wskazówki, mimo swego werdyktu nad Lutrem: kiedy przy pomocy niezależnego poznania skonfrontował teologiczną tradycję średniowiecza z reformacją, zwłaszcza z luterańską nauką o usprawiedliwieniu, skierował on spojrzenie na zapoznany dotąd teren. Słusznie napisał Merkle o dziele Deniflego: „To, co w nim nieprzemijalne, to strona historyczno-dogmatyczna" (s. 201). Do tego doszło również i to, że Denifle zwrócił uwagę na rozwój „młodego Lutra”. Zarówno Luter i scholastyka oraz młody Luter stały się odtąd standartowymi tematami międzynarodowych badań luterańskich.

Mniej więcej w siedem lat po ukazaniu się książki Deniflego, katolickie badania nad Lutrem wydały drugie obszerne dzieło. Jezuita Hartmann Grisar opublikował w r. 1911 trzytomową pracę o Lutrze. Jego język 
był wyraźnie powściągliwszy niż Deniflego, a w ocenie Lutra kierował się innym zamiarem. Luter był teraz psychopatą, którego chorobliwe usposobienie, zwłaszcza jego zarozumiałość i przecenianie siebie samego stały się przyczynami reformacji. Hubert Jedin osądza Grisara tak: „Jego psychologiczno-patologiczna interpretacja jest $w$ stosunku do niego [tzn. Lutral mniej niesprawiedliwa aniżeli twarde odrzucenie dominikanina; badania nad Lutrem nie osiągnęły przez niego istotnego postępu".

Jeżeli jednak pomimo takiego $\mathrm{w}$ gruncie rzeczy negatywnego obrazu Lutra ze strony katolickiej doszło w Niemczech do rzeczowej oceny wittenberskiego reformatora, a przez to do podniecającej ,przygody" katolickich badan nad Lutrem, to miało to następujące przyczyny.

1. Rewizja ewangelickiego obrazu Lutra, interpretowanego np. w latach dwudziestych $w$ tzw. szkole Holla już teologiczno-religijnie, a nie niemiecko-narodowo, przez co obraz ten działał mniej prowokacyjnie. Do dzisiaj ślady tej szkoły występują we wszystkich wyznaniach. Ogólnie rzecz biorąc, doszło $\mathrm{w}$ protestantyzmie do miarodajnych prac o Lutrze.

2. Metoda współczesnej nauki historycznej, czyli metoda historyczno-krytyczna, jaką posługiwano się już na przełomie wieków w tzw. katolicyzmie reformowanym. Spowodowała ona zbliżenie rozdzielonych wyznaniowo historyków Kościoła na bazie rzeczowej interpretacji źródeł.

3. Naukowcy mający dość sił do systematycznego posługiwania się tą metodą. Należy w tym miejscu ponownie wymienić Sebastiana Merkla $(† 1945)$, który $w$ obszernych omówieniach i odczytach starał się naukowo - nie ekumenicznie! - ocenić Lutra sprawiedliwie, co powoli wychodziło na dobre ukierunkowanemu na źródła i bezpolemicznemu sposobowi pracy.

4. Pewne racje przemawiają za tym, że sytuacja polityczna w Niemczech po pierwszej wojnie światowej oraz wewnętrzne rozdarcie Republiki Weimarskiej przynaglały - przynajmniej wyznaniowo - do jedności, co okazało się korzystne dla katolickich badań nad Lutrem i reformacją.

Po tym, co wyżej powiedziano, nie jest żadnym przypadkiem, że właśnie uczeń Merklego, ratyzboński dziekan katedralny Franz Xaver Kiefl, krótko przed zakończeniem wojny opublikował (1917) w renomowanym czasopiśmie „Hochland” artykuł pod tytułem: Martin Luthers religiöse Psyche, gdzie ocenił pozytywnie religijną osobowość reformatora, opanowaną przez centralną ideę wyłącznej sprawczości Bożej. Kiefl zarzucił przez to psychologiczno-patologiczną interpretację Grisara i utorował drogę do religijnej oceny Lutra. Przy tym powodowały nim nie tylko racje naukowe $w$ jego przyjaznym osądzie. Pragnienie narodowej jedności oraz strach przed ,zagrożeniem marksistowskiego rozumienia historii w dzie37 - Analecta Cracoviensia 
dzinie religijnej” („Hochland” 15/1 s. 7) sprawiły, że Kiefl myślał ekumenicznie i interpretował religijnie historię, w tym przypadku reformatora Lutra.

Jednakże tym, co historycznie oddziałało na treść papieskiego listu, tym nie był bynajmniej pozytywny obraz Lutra wypracowany przez Merklego i Kiefla. Trzeba było jeszcze dwóch dziesięcioleci zanim ukazała się książka, której słusznie przypadła kluczowa rola w katolickim badaniu Lutra. Chodzi o dwutomowe dzieło Józefa Lortza: Die Reformation in Deutschland, wydane w latach 1939-40, które doczekało się już 6 wydań. Religijność Lutra w tej wielkiej i często czytanej pracy została oceniona pozytywnie daleko bardziej niż to uczynił Kiefl, a działalność Lutra na tle Kościoła czekającego raczej reformy niż dojrzałego, Kościoła - którego biskupi już od dawna nie dorastali do swoich zadań, stała się zrozumiała. Jednocześnie pojawiło się zdanie, często do dziś powtarzane: „Luter pokonał w sobie katolicyzm, który nie był katolicki" (t. 1, s. 176). Dla Lortza oznaczało to, że Luter skierował swoje ataki nie przeciwko prawdziwemu katolicyzmowi, lecz przeciwko nominalistyczno-ockhamistowskiej teologii, która stała się właśnie zafałszowaniem tego, co prawdziwie katolickie. Osobowość Lutra, obok wielu pozytywnych rysów, miała - według Lortza - również pewną negatywną stronę, ważną dla reformacji: jego subiektywizm, podtrzymany teologicznie przez ockhamizm. Pisze on: ,[...] obok duchowej skłonności są również pewne zasadnicze postawy teologiczne, które charakteryzują Lutra najgłębiej od strony subiektywizmu". Ponieważ osobowość skłonna do subiektywizmu spotkała się tutaj z odpowiednią teologią, tendencja ta zaostrzyła się. Dlatego też Luter nie był żadnym dyletantem (,Vollhörer”) w zakresie Pisma świętego.

Nie można zatem mówić o bezkrytycznym obrazie Lutra u Lortza. Jednakże jego wielkie osiągnięcie, oparte na Merklu o wiele bardziej niż to się dotąd przypuszcza, polegało na tym, że uznał on reformę za sprawę według Lutra niezmiernie pilną i już nie oceniał jej negatywnie, lecz pozytywnie; reformator uchwycił coś rdzennie katolickiego. Luter jako "homo religiosus" — ta kwalifikacja jest u Lortza imponująca, a w późniejszych opracowaniach jeszcze ją pogłębił. Jej ślady prowadzą wyraźnie aż do listu papieskiego. Jeżeli powiedziano w nim: „Przekonywująco dostrzegalna stała się przy tym głęboka religijność Lutra, stawiającego z gorącą namiętnością pytania o wieczne zbawienie. Stało się też oczywiście jasne, że zerwania jedności Kościoła nie można sprowadzić ani do arogancji pasterzy [...] ani też do braku zrozumienia prawdziwego katolicyzmu ze strony Lutra", to tu została uchwycona zarówno myśl Lortza o religijnej osobowości Lutra, jak i jego obraz Kościoła dojrzewającego do reformy, którego pasterze nie dorastali do swoich zadan. Rów- 
nịez Lutrowe niezrozumienie katolicyzmu, mocno podkreślone przez Lort$\mathrm{za}$, zostało tu zaznaczone - jednakże zawsze $\mathrm{z}$ poprawkami odpowiadającymi stanowi badań.

Prawie równolegle do książki Lortza historyk Kościoła z Paderborn Adolf Herte wykazał (1943), że katolicki obraz Lutra znajdował się przez wieki pod zniekształcającym go wpływem kontrowersyjnego teologa z XVI wieku, mianowicie Jana Cochläusa, którego Commentaria de actis et scriptis Martini Lutheri zaciążyła na późniejszej historiografii. Odkrycie Hertego rozkurczyło katolickie badanie nad Lutrem i uwolniło je do pewnego stopnia od negatywnej strony swej własnej tradycji. Oczywiście, Herte z trudem uniknąl - jak o tym dziś wiemy - kościelnego potępienia.

Nazwiska Lortza i Hertego oznaczały wyraźną zmianę klimatu i rzeczowość w kształtowaniu obrazu Lutra przez katolicką historiografię kościelną niemiecką. Szczęśliwy przypadek zrządził, że Lortzowi, jako akademickiemu nauczycielowi w Moguncji i kierownikowi Instytutu Europejskiej Historii - Wydział Historii Religii, udało się wykształcić szereg wpływowych uczniów, którzy kontynuowali jego dzieło i koncepcję. W dzisiejszych katolickich badaniach nad Lutrem są nimi przede wsizystkim Erwin Iserloh i Peter Manns. W ten sposób zarysowany przez Lortza obraz Lutra został przekazany dalej z odpowiednimi modyfikacjami. Manns, następca Lortza w Moguncji, zintensyfikował badania w kierunku teorii tzw. „katolickiego Lutra”. Jeżeli już Lortz uważał, że Luter odkrył na nowo w swej nauce o usprawiedliwieniu coś prakatolickiego, to Manns w wydanej w r. 1982 książce Martin Luther poszedł jeszcze krok do przodu. Wbrew tradycyjnemu poglądowi naukowemu stwierdza on, że Luter nie wyrugował teologicznej cnoty miłości przez wiarę (por. komentarz Lutra do listu do Galatów z r. 1531: „W miejsce miłości stawiamy wiarę"), lecz jego specyficzne pojęcie wiary wchłonęło miłość. Przez to był on bardziej katolicki niż przyjmowali to jego współcześni, Gegner i zwolennicy. Manns pisze (s. 87):

Jeśli moja teza jest słuszna, to pierwotnej teologii Lutra nie da się od strony wyzntaczającej i ożywiającej ją kwestii zasadniczej przenieść ani do konfesyjnie 'katolickiego', ani do 'reformowanego' wyznania, chociaż naturalnie przykazanie miłości ¿uga wiąże zarówno Kościół papieski, jak i Kościół reformowany. Dlatego to właśnie obsrzano się na Lutra, że on - sam osobiście do końca życia zawsze w pierw:zym szeregu - rozsadzał granice starego Kościoła, nie występując z niego jednoczesnie $z$ tego powodu, a także że nie wszedł on do żadnego nowego Kościoła', ktrogego granice wyznaczałoby zasadniczo to, co zostało odrzucone jako katolickie'. Bez wdawania się w merytoryczną dyskusję, chciałbym zgłosić wątpliwość co do takjej interpretacji. Nie wyjaśnia ona ostatecznie, dlaczego Luter w ogóle stał się vetormatorem. 
Erwin Iserloh, drugi wybitny uczeń Lortza, tak dalece podtrzymał jego rozmach, że do dziś zalicza on Lutra do zakresu ockhamistyczno-subiektywistycznej teologii. Czy tezę tę da się utrzymać w przyszłości, jest rzeczą sporną, ponieważ najnowsze badania Adolara Zumkellera wykazały, że erfurccy augustianie, których członkiem był Luter, nie podlegali wpływom Ockhama, co mogłoby przybliżyć wnioski odnośnie do Lutra (A. Z u mkelle r, Erbsïnde, Gnade, Rechtfertigung und Verdienst nach der Lehre der Erfurter Augustinertheologen des Spätmittelalters, 1984). Iserloh wzbudził jednak sensację innym odkryciem i zmienił katolicki obraz Lutra. Od r. 1961 kwestionuje on nie bez słuszności fakt zawieszenia przez Lutra 31 października 1517 r. 95 tez na kościele zamkowym $\mathrm{w}$ Wittenberdze. Wyciąga on $\mathrm{z}$ tego interesujące wnioski odnośnie do obrazu Lutra: Luter nie rozpoczął jako rewolucjonista, lecz jako spontaniczny reformator. Kompetentni biskupi wzięli na siebie ciężką winę, ponieważ nie zareagowali na to w sposób duszpastersko odpowiedzialny. Zdaniem Iserloha, Luter już w r. 1517 rozwinął swoją centralną naukę o usprawiedliwieniu sola fide, ale nie myślał o podziale Kościoła jako konsekwencji, i dlatego zajęte później pozycje musiały rozdzielić Kościół. Za to od r. 1519 zostały zakwestionowane eklezjologiczne nauki, Opinię Iserloha, że nie usprawiedliwienie, lecz eklezjologia doprowadziła do rozdziału, podziela dzisiaj większość katolickich badaczy Lutra. Ewangelicka teologia zgłasza, co prawda, wątpliwości i zwraca uwagę na wewnętrzne powiązanie obu punktów nauki Lutra, czego nie wolno przeoczyć. „Iustificatio sola fide” warunkuje nowy obraz Kościoła.

Dokładnie w tym dogmatycznym punkcie, w zasadzie nie przedyskutowanym jeszcze, można umieścić drugą wspomnianą wyżej tezę moich rozważań. To, do czego odwołuje się druga część papieskiego listu, po ocenie religijnej osobowości Lutra, to dogmatyczna strona jego teologii i jej oddziaływanie na Kościół ewangelicki, przy czym czysto historyczny wymiar zostaje tu przekroczony na korzyść pryncypialnego dialogu na temat struktur przyswojenia wiary chrześcijańskiej. Należy zatem przedyskutować teologiczne zagadnienia $w$ rozmowie $z$ Lutrem i o nim, które z wewnętrznej konieczności przekraczają czysto historyczną interpretację i prowadzą do systematyczności. List przyporządkowuje słusznie tę tematykę ekumenicznemu dialogowi, gdzie - wraz z Lutrem lub bez niego - pytania te się narzucają. Samym historycznym rozumieniem nie da się ustanowić jedności Kościoła.

Gdybyśmy prześledzili pod tym kątem widzenia drogę i zmianę kato- 
lickiego obrazu Lutra, poczynilibyśmy bardzo interesującą obserwację, jak od lat sześćdziesiątych przy zajmowaniu się teologią reformatora rozwijał się w Niemczech pogląd, który można by nazwać dogmatyczno-systematycznym. Chodziło tutaj nie o kontrowersyjno-teologiczne rozliczanie się z reformacją Lutra - tak jak ono w Kościele katolickim przez cały czas mniej lub więcej było żywotne - lecz o nowe systematyczne podejście do historycznego Lutra, biorące poważnie ten historyczny wymiar i o uwzględnienie w tej mierze historyków Kościoła. W tym czasie rozwinięto $\mathrm{w}$ różnych kierunkach tę stronę badań nad Lutrem jako konieczne uzupełnienie czysto historycznej metody, chociaż nie można jeszcze było mówić o ostatecznym wyniku. Schematycznie dadzą się rozróżnić trzy możliwe stanowiska:

1. Linię ukierunkowaną, ,ponadekumenicznie” reprezentuje Otto Hermann Pesch, katolik i były dominikanin, wykładający obecnie teologię ekumeniczną na wydziale ewangelicko-katolickim Uniwersytetu Hamburskiego (por. O. H. Pes ch, Gerechtfertigt aus Glauben. Luthers Frage an die Kirche, Freiburg 1982). Jego dogmatyczny aksjomat wychodzi z następującego założenia: do teologii Lutra, podporządkowanej tzw. ,teologii egzystencjalnej” - w przeciwieństwie do ,teologii sapiencjalnej” św. Tomasza z Akwinu - należy przykładać nie tylko miarę szesnastowieczną, lecz także teologie pozytywną, jaka rozwinęła się po Soborze Watykańskim II. Pesch nie chce przez to zdewaluować historyczno-krytycznego sposobu interpretacji, ale go przezwyciężyć, ponieważ - jego zdaniem jest on niewystarczający dla ekumenicznej recepcji Lutra. Chodzi mu o to, aby ze strony katolickiej pojąć Lutra ,,jako własną możliwość teologicznego myślenia i bytowania”. Jego podstawowa teza brzmi: „Jądro kontrowersji o 'historyczną' i 'systematyczno-ekumeniczną' interpretację Lutra tkwi właściwie w pytaniu, czy może być dzisiaj 'katolickie' to, co kiedyś było 'niekatolickie" (Ökumenische Erschliessung M. Luthers, 53). Za pomocą takiego postępowania chce on wykazać, że wprawdzie dla teologii szesnastowiecznej Lutrowa nauka o usprawiedliwieniu i jego eklezjologia były czynnikiem destrukcyjnym w Kościele, ale nie muszą one takimi być stosownie do stanu dzisiejszej teologii katolickiej. Jednakże katolicka, jak również ewangelicka historiografia kościelna odnoszą się sceptycznie do takiego sposobu pracy, a to z racji metodycznych, tak iż nic dziwnego, że Pesch od początku pozostaje $\mathrm{w}$ sporze $\mathrm{z}$ historykami. Można zapytać, czy tego rodzaju aktualizacja Lutra przysłuży się w ostatecznym rozrachunku ekumenizmowi i prawdzie, skoro bierze za mało poważnie historyczną sytuację.

2. W zupełnym przeciwieństwie do tego „ponadekumenicznie” ukierunkowanego założenia Pescha rozwinięto w ostatnich latach systema- 
tyczne objaśnianie Lutra, gdzie uprawia się fundamentalną krytykę reformatora. I tak np. w r. 1980 ukazało się drugie poprawione wydanie książki Theobalda Beera pod osobliwym tytułem: Der fröhliche Wechsel und Streit. Grundzüge der Theologie Martin Luthers (Einsiedeln 1980); jej autor odrzuca chrystologię Lutra jako niebiblijną i pseudognostyczną. Niebezpieczeństwo popadnięcia $w$ starą polemikę leży tu $\mathrm{w}$ zasięgu ręki przede wszystkim dlatego, że Beer samowolnie ignoruje wszystkie wyniki współczesnych katolickich badań nad Lutrem. Z tych racji został on surowo skrytykowany przez reprezentatywnych historyków Kościoła, jak Erwin Iserloh (,Catholica” 36, 1982, s. 101-114).

3. Jako pogląd systematycznie ukierunkowany ad rem i stanowiący tutaj jakiś postęp, można wymienić przykładowo szczegółowy referat Karla Lehmanna, obecnego biskupa Moguncji, wygłoszony w r. 1981 pod tytułem: Luther in der modernen katholisch-systematischen Theologie (w: Zur Lage der Lutherforschung heute. Ifg. von P. Manns, Wiesbaden 1982 , s. 79-89). Lehmann wymienia jako główne problemy następujące: „Nauka o ukrytym Bogu i teologia krzyża; intensywne zajęcie się teologią Lutra i jej implikacjami; Lutrowe pojmowanie Pisma św., jasność Pisma św., Pismo św., a Tradycja; centralne tematy nauki o usprawiedliwieniu, które żadną miarą nie są załatwione, nawet jeżeli nie uchodzą już za czyniące podział w Kościele; [...] nauka o Kościele; [...] Lutrowe rozumienie Słowa i Sakramentu; zasadnicze twierdzenia eschatologiczne; cześć świętych i Marii".

Jeżeli list papieski mówi o ,zasadniczych kwestiach właściwego wyłożenia i przyswojenia wiary chrześcijańskiej”, których „działania powodującego podział w Kościele nie udało się przezwyciężyć li tylko samym historycznym rozumieniem", to można się tu domyślać, że nie ma on na uwadze ani jednostronnej ekumenicznej linii badań nad Lutrem, jak ją praktykuje Pesch, ani werdyktów Beera nad Lutrem, ale problemy naprawdę zasadnicze, jak je sformułował Lehmann, a które w istocie domagają się udziału dogmatyka obok historyka.

Przemierzyliśmy odcinek drogi niemieckiego katolickiego piśmiennictwa kościelnego i przypatrzyliśmy się pewnym ważnym etapom ,przygody badan nad Lutrem", o których to badaniach francuski teolog Marc Lienhard powiedział, że należą do „najbardziej denerwujących rozdziałów badań nad Lutrem w ogóle". List papieski służył za przewodnika, dokumentując wyniki oraz ich oficjalną recepcję, a także granice i nieod- 
zowny drugi systematyczny tor katolickich badań nad Lutrem. W związku z tym postawmy na koniec raz jeszcze pytanie: jakie znaczenie posiadają w Niemczech katolickie zabiegi wokół Lutra? Odpowiedź na nie można ująć zwięźle w kilku zdaniach.

1. Znaczenie historycznego badania powinno dla ekumenizmu stać się wystarczająco jasne poprzez przemówienie kard. Willebrandsa $\mathrm{z} r$. 1970 i list papieski z r. 1983. Sytuacja w Niemczech, w kraju wyznaniowo podzielonym i w szerokich kręgach ciągle jeszcze pojmowanym jako „kraj pochodzenia reformacji”, jest określona przez to, że po drugiej wojnie światowej zaistniał ruch ekumeniczny, który między innymi był uwarunkowany wspólnym doświadczeniem wyznań $\mathrm{w}$ walce $\mathrm{z}$ narodowym socjalizmem. Do tego doszło silniejsze wymieszanie przynależności wyznaniowej w strukturze społecznej spowodowane przemieszczaniem się ludności wewnątrz Niemiec, jakie obserwowało się po r. 1945. Poza tym coraz bardziej szerząca się sekularyzacja życia czyni współpracę kościołów koniecznością życiową. Skoro jednak dla luterańskich chrześcijan, stanowiących około 17\% ludności RFN hasło: „Bez Lutra nie ma ekumenizmu", pozostaje aktualne, przeto katolicki obraz Lutra posiada dla ekumenicznego dialogu najwyższe znaczenie. Nawet tam, gdzie chętnie mówi się o pewnym ,zapomnieniu Lutra" w protestantyzmie (Ebeling), jego teologia oddziałuje nadal strukturalnie, a on sam jest odpowiednią postacią, by działać jako czynnik tożsamości wyznań. Im bardziej katolickiemu i ewangelickiemu badaniu historycznemu udaje się wypracować obraz Lutra teologicznie i historycznie właściwy, tym pozytywniej odbija siẹ ta praca na stosunkach wyznaniowych. Rok Luterański 1983, świętowany w Niemczech intensywnie, był doskonałym dowodem uprzedmiotowanego skutkowania badań historycznych. Już teraz można powiedzieć, że $w \in$ jozie on do historii jako ,ekumeniczny rok luterański”.

2. Skutki katolickich historyczno-kościelnych badań nad Lutrem zaowocowały nie tylko w dialogu ekumenicznym, lecz także ożywiły i ubogacily ewangelickie badania $\mathrm{w}$ tym zakresie. Pytania o zakorzenienie Lutra w scholastyce, o jego pojęcie Kościoła, jego postulaty na tle istniejącego od dłuższego czasu katolickiego ruchu reformy - wszystko to zostało na nowo naświetlone i poszerzyło perspektywy. Nie ma dziś kongresu luterańskiego, na którym nie występowaliby razem teolodzy katoliccy i ewangeliccy.

3. Można wreszcie wysunąć przypuszczenie, że katolickie prace o Lutrze przyczynily się do skierowania spojrzenia katolickiego dziejopisarstwa w Niemczech na centralny punkt naszej historiografii. Jeżeli się pomyśli, że niemieckie akademickie badania historyczne pozostawały od XIX wieku domeną protestantów, to także tutaj osiągnięto duży postęp na terenie pozateologicznym. 
4. O ile nie ma dziś pełnego, jednoznacznego, katolickiego obrazu Lutra, o tyle będzie to konieczne i możliwe również w przyszłości. Historia Kościoła i systematyka powinny troszczyć się nadal o prawdę we właściwej analizie źródeł i interpretacji, a tym samym o możliwie najbardziej całościowy obraz Lutra, gdyż ostatecznie tylko to służy teologii i jedności chrześcijan. 